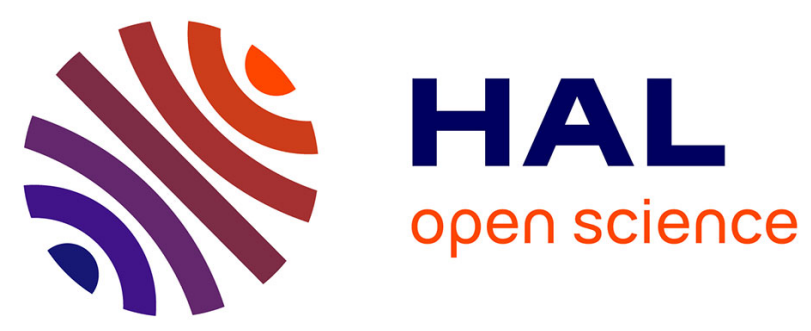

\title{
A tale of two Spartinas: Climatic, photobiological and isotopic insights on the fitness of non-indigenous versus native species
}

Bernado Duarte, Alexandra Baeta, Mathieu Rousseau-Gueutin, Malika L. Ainouche, Joao Carlos Marques, Isabel Caçador

\section{To cite this version:}

Bernado Duarte, Alexandra Baeta, Mathieu Rousseau-Gueutin, Malika L. Ainouche, Joao Carlos Marques, et al.. A tale of two Spartinas: Climatic, photobiological and isotopic insights on the fitness of non-indigenous versus native species. Estuarine, Coastal and Shelf Science, 2015, 167, pp.178-190. 10.1016/j.ecss.2015.06.015 . hal-01170439

HAL Id: hal-01170439

https://hal-univ-rennes1.archives-ouvertes.fr/hal-01170439

Submitted on 19 Nov 2015

HAL is a multi-disciplinary open access archive for the deposit and dissemination of scientific research documents, whether they are published or not. The documents may come from teaching and research institutions in France or abroad, or from public or private research centers.
L'archive ouverte pluridisciplinaire HAL, est destinée au dépôt et à la diffusion de documents scientifiques de niveau recherche, publiés ou non, émanant des établissements d'enseignement et de recherche français ou étrangers, des laboratoires publics ou privés. 
A Tale of Two Spartinas: climatic, photobiological and isotopic insights on the fitness of nonindigenous versus native species

Duarte, B. ${ }^{1 *}$, Baeta, A. ${ }^{2}$, Rousseau-Gueutin, M. ${ }^{3}$, Ainouche, M. ${ }^{3}$, Marques, J.C. ${ }^{2}$ and Caçador, I. ${ }^{1}$

${ }^{1}$ MARE - Marine and Environmental Sciences Centre, Faculty of Sciences of the University of Lisbon, Campo Grande 1749-016 Lisbon, Portugal.

${ }^{2}$ MARE - Marine and Environmental Sciences Centre, Faculty of Sciences and Technology, University of Coimbra, 3000 Coimbra, Portugal.

${ }^{3}$ UMR CNRS 6553 Ecobio, University of Rennes 1 (France).

* Corresponding Author: Bernardo Duarte, email: baduarte@fc.ul.pt

\section{Abstract}

Salt marshes are facing a new threat: the invasion by non-indigenous species (NIS), Although its introduction time is not established yet, in 1999 Spartina versicolor was already identified as a NIS in the Mediterranean marshes, significantly spreading its area of colonization. Using the Mediterranean native Spartina maritima as a reference, the present research studied the ecophysiological fitness of this NIS in its new environment, as a tool to understand its potential invasiveness. It was found that Spartina versicolor had a stable photobiological pattern, with only minor fluctuations during an annual cycle, and lower efficiencies comparated to S. maritima. The NIS seems to be rather insensitive to the observed abiotic factors fluctuations (salinity and $\mathrm{pH}$ of the sediment), and thus contrasts with the native S. maritima, known to be salinity dependent with higher productivity values in higher salinity environments. Most of the differences observed between the photobiology of these species could be explained by their nitrogen nutrition (here evaluated by the $\delta^{15} \mathrm{~N}$ stable isotope) and directly related with the Mediterranean climate. Enhanced by a higher $\mathrm{N}$ availability during winter, the primary production of $\mathrm{S}$. maritima which lead to dilution of the foliar $\delta^{15} \mathrm{~N}$ concentration in the newly formed biomass, similarly to what is observed along a rainfall gradient. On the other hand, S. versicolor showed an increased $\delta^{15} \mathrm{~N}$ in its tissues along the annual rainfall gradient, probably due to a $\delta^{15} \mathrm{~N}$ concentration effect during low biomass production periods (winter and autumn). Together with the photobiological traits, these isotopic data point out to a climatic misfit of S. versicolor to the Mediterranean climate compared to the native S. maritima. This appears to be the major constrain shaping the ecophysiological fitness of this NIS, its primary production and consequently, its spreading rate along the Mediterranean marshes.

Keywords: S. maritima; S. versicolor; photosynthesis; N nutrition; ecophysiological fitness

\section{Introduction}


The Spartina genus is one of the most successful among halophytes, being present in a wide range of latitudes across the globe. Some studies have already described latitudinal population differentiation of Spartina species (Seliskar et al., 2002; Lessmann et al., 1997; Daehler et al., 1999; Otero et al., 2000; Proffitt et al., 2005; Álvarez et al., 2010; Duarte et al., 2013). Members of the Spartina genus present a $\mathrm{C}_{4}$-type photosynthesis, based on phosphoenolpyruvate carboxylase (PEPC) activity to concentrate $\mathrm{CO}_{2}$ at higher rates than it would be observed in a $\mathrm{C}_{3}$ organism (Hatch, 1992; Álvarez et al., 2010). In spite of this metabolic advantage, PEPC activity relies on light-dependent phosphorylation (Vidal et al., 1996), making it dependent on the surrounding climatic environment. Differences among species and populations are expected, due to sensitivity to pressures, such as climatic variation, contaminants and grazing (Heide, 2005; Stephenson et al. 2006). In addition, the activation of PEPC by a specific kinase is poor at low light intensities (Bailey et al. 2007) and during cold temperatures (Lara et al. 2001), being both these factors latitude-dependent.

The invasion of natural communities by non-indigenous species (NIS) represents one of the most serious threats to biodiversity (Heywood, 1989). While these invasive processes are rather well studied in river corridors and riparian communities, (Planty-Tabacchi et al., 1996 and 2001; Tabacchi and Planty-Tabacchi, 2002), the invasiveness of non-indigenous aquatic plants in wetlands has received far less attention. Many NIS plants have been introduced more than 100 years ago, while others are more recent arrivals, with the majority of the introductions occurring in the end of the $19^{\text {th }}$ and at the beginning of the $20^{\text {th }}$ centuries (Thiébaut, 2007). Spartina versicolor Fabre was first described in the Mediterranean region during the $19^{\text {th }}$ century (Fabre, 1849). Several authors consider that this taxon originated in America, and was introduced in Europe (Cosson and Durieu, 1867; Fernald, 1929; Mobberley, 1956; Hultén, 1958). It is probable that this species was introduced as packing material in crates to various ports around the Mediterranean Sea (SanLeón et al., 1999). Nowadays it is highly present all over the west Galician coast, with some populations already identified also in north Spain (SanLeón et al., 1999) and in several estuaries and coastal lagoons from the west coast of Portugal (Baumel et al., submitted). This specie normally colonizes the upper and middle marsh in sandy or muddy-sandy sediments, with potential to compete mainly with the halophytic shrubs characteristic from these areas (for e.g. Halimione portulacoides, and Sarcocornia fruticosa). Although the records of its presence in the Iberian Peninsula are scarce, in 1999 it was only reported in four estuaries of the West Atlantic coast of Portugal (SanLeón et al., 1999) and nowadays it is present in several other coastal systems (Baumel et al., submitted; personal observation). Its rhizomatous character puts at risk the presence and survival of native species in the Mediterranean marshes, similarly to what was observed in other latitudes (Dahler and Strong, 1996). These S. versicolor populations have been recorded with a similar distribution to that observed for S. maritima (Curtis) Fernald, native from the Atlantic African and European 
Atlantic coasts (Marchant and Goodman, 1969). Having the native S. maritima as reference, it becomes important to evaluate whether the fast colonization of $S$. versicolor, already verified in other Iberian marshes (SanLeón et al., 1999), may lead to the loss of the indigenous species. It is known that S. maritima photosynthetic metabolism is not nutrient-limited due to the tidal regime to which is subjected that provides nutrient supply twice per day (Duarte et al., 2013; Duarte et al., 2014). Nevertheless these features are unknown for these S. versicolor populations. The rate and efficiency of light use can also modulate biomass production (Duarte et al., 2013), and is a key factor in the expansion and/or maintenance of the areas colonized by S. maritima and S. versicolor.

The aim of this study was to evaluate the ecophysiological fitness of the NIS S. versicolor while comparing it with the traits exhibited by the indigenous S. maritima. For this a mixed approach evaluating the species photobiology and its relation with $\mathrm{N}$ acquisition will be attained.. This approach was already applied in previous works (Duarte et al., 2013) in order disentangle the traits underlying different populations of S. maritima. Considering this, a similar approach was taken to compare neighbor species with a high degree of taxonomic proximity. This will allow a better understanding of their seasonal primary production dynamics as well as assessing the ecological tolerance of both native and NIS species to the Mediterranean climate.

\section{MATERIAL AND METHODS}

\subsection{Study area and sampling}

Spartina individuals were all sampled from November 2012 to July 2013 in Hortas salt marsh (Tagus Estuary, Fig. 1). The Tagus Estuary climatic regime fits the Mediterranean classification (details in Table 1). Climatic data collection was withdrawn from the public database from the Portuguese National Institute of Water (www.snirh.pt). For a more robust dataset, the data regarding the last 10 years was used where available and seasonal averages were calculated, in order to characterize climatically the studied periods. Data relative to air temperature, relative humidity, precipitation and radiation were consulted directly in the database, while potential evapotranspiration was calculated using a modified Turc method (Turc, 1961; Douglas et al., 2009):

$E T=0.013 \times\left(23.88 \times R_{S}+50\right) \times\left(\frac{T}{T+15}\right)$

where $E T$ is potential evapotranspiration in $\mathrm{mm} /$ day, $R_{S}$ is solar radiation in $\mathrm{MJ} \mathrm{m}^{-2} \mathrm{~d}^{-1}$, and $T$ is average daily air temperature.

The Hortas salt marsh is a young undisturbed salt marsh located within the Tagus Estuary Natural Reserve (Duarte et al., 2013) and thus provides an anthropogenic interference-free approach. Climatic data collection was withdrawn from the public database from the Portuguese National Institute of Water (www.snirh.pt). For a more robust dataset, the data regarding the last 
10 years was used where available and seasonal averages were calculated, in order to characterize climatically the studied periods. Data relative to air temperature, relative humidity, precipitation and radiation were consulted directly in the database, while potential evapotranspiration was calculated using a modified Turc method (Turc, 1961; Douglas et al., 2009). The sampling sites were composed of five large extensions of S. maritima and NIS S. versicolor. Each pure stand was considered as an experimental unit (replicate). All five stands from each species were chosen considering their similar position along the marsh to minimize elevation-driven differences. Both species are located close together along the salt marsh, separated just by a few meters. Spartina maritima samples were collected in the low mash near the mudflat and S. versicolor samples were collected in the upper marsh. Leaves were harvested and immediately stored in liquid nitrogen and brought back to the laboratory, where they were kept at $-80{ }^{\circ} \mathrm{C}$ until analyses. Sediment samples $(n=5)$ were also collected in pure stands of the selected species, using PVC tubular cores $(9 \mathrm{~cm}$ diameter, $50 \mathrm{~cm}$ long) and transported to the lab in refrigerated bags where they were sliced.

\subsection{Sediment physical-chemical analysis}

All the analyses were carried out using sediment samples from depth between 5-8 cm, due to the high influence of the root system at this depth (Duarte et al., 2008 and 2009). Sediment relative water content (RWC) was determined by drying sediment samples at $60^{\circ} \mathrm{C}$ until constant weight. Pore water salinity was measured with a hand refractometer, after pore water extraction by centrifugation at $14,000 \mathrm{~g}$ for $15 \mathrm{~min}$ at $4^{\circ} \mathrm{C}$. Organic matter was determined by the loss on ignition (LOI) method by burning $1 \mathrm{~g}$ of air-dried sediment at $600^{\circ} \mathrm{C}$ for $3 \mathrm{~h}$.

\subsection{Plant leaf stable isotope analysis}

The carbon and nitrogen isotopic composition of the pulverized leaf samples were determined using a Flash EA 1112 Series elemental analyser coupled online via Finningan conflo III interface to a Thermo delta V S mass spectrometer. The carbon an nitrogen isotope ratio were expressed in delta $(\delta)$ notation, defined as the parts per thousand $(\%)$ deviation from a standard material (PDB limestone for $\delta^{13} \mathrm{C}$ and $\mathrm{N}_{2}$ in air for $\delta^{15} \mathrm{~N}$ ) using the following formula: $\delta^{13} \mathrm{C}$ or $\delta^{15} \mathrm{~N}=\left[\left(R_{\text {sample }} / R_{\text {standard }}\right)-1\right] \times 10^{3}$, where $R$ is ${ }^{13} \mathrm{C} /{ }^{12} \mathrm{C}$ or ${ }^{15} \mathrm{~N} /{ }^{14} \mathrm{~N}$. The analytical precision for the measurement was $0.2 \%$ for both isotopes. Carbon and nitrogen contents (\%) were determined simultaneously using the same procedure.

\subsection{Pigment analysis}

Leaves for pigment analysis were freeze-dried in the dark during $48 \mathrm{~h}$, after which they were grounded in pure acetone with a glass rod. To ensure complete disaggregation of the leaf material, samples were subjected to a cold ultra-sound bath for $2 \mathrm{~min}$. Extraction occurred at -20 
o $\mathrm{C}$ for $24 \mathrm{~h}$ in the dark to prevent pigment degradation. After extraction samples were centrifuged at $4000 \mathrm{rpm}$ for $15 \mathrm{~min}$ at $4 \stackrel{\circ}{\circ}$. Gauss-Peak Spectra method was used to determine pigment concentrations (Kupper et al., 2007). Samples were scanned in a dual beam spectrophotometer from $350 \mathrm{~nm}$ to $750 \mathrm{~nm}$ at $0.5 \mathrm{~nm}$ steps. The absorbance spectrum was introduced in the GPS fitting library, using SigmaPlot Software. Total chlorophylls and carotenoids were assessed by polling pigments from each group into total chlorophylls and total carotenoids.

\subsection{PAM fluorometry}

Modulated chlorophyll fluorescence measurements were performed in attached leaves in the field using a FluoroPen FP100 PAM (Photo System Instruments, Czech Republic). All the measurements in the dark-adapted state were realised after darkening of the leaves for at least 30 min. The minimal fluorescence $\left(F_{0}\right)$ in dark-adapted state was determined by measuring the modulated light that was sufficiently low $\left(<0.1 \mu \mathrm{mol} \mathrm{m} \mathrm{s}^{-2}\right)$ to not induce any significant variation in fluorescence, The maximal fluorescence level $\left(F_{M}\right)$ in dark-adapted state was measured by a 0.8 seconds saturating pulse at $8000 \mu \mathrm{mol} \mathrm{m} \mathrm{m}^{-2} \mathrm{~s}^{-1}$. The maximum photochemical efficiency was assessed as $\left(\mathrm{F}_{\mathrm{M}}-\mathrm{F}_{0}\right) / \mathrm{F}_{\mathrm{M}}$. The same parameters were also measured in light-adapted leaves, being $\mathrm{F}_{0}$ the minimum fluorescence, $F_{M}^{\prime}$ the maximum fluorescence and the operational photochemical efficiency. Rapid light curves (RLC) measurements, in dark-adapted leaves, were attained using the pre-programmed LC1 protocol of the FluoroPen, consisting in a sequence of pulses from 0 to 500 $\mu \mathrm{mol} \mathrm{m} \mathrm{s}^{-2}$. During this protocol the $\mathrm{F}_{0}$ and $\mathrm{F}_{\mathrm{M}}$ as well as the maximum photochemical efficiency were measured. Each $\Phi_{\text {PSII }}$ measurement was used to calculate the electron transport rate (ETR) through photosystem II using the following equation: ETR $=\Phi_{\text {PSII }} \times$ PAR $\times 0.5$, where PAR is the actinic photosynthetically active radiation generated by the FluoroPen and 0.5 assumes that the photons absorbed are equally partitioned between PSII and PSI (Genty et al., 1989). Without any knowledge of the actual amount of light being absorbed, fluorescence measurements can only be used as an approximation for electron transport (Beer et al., 1998a, Beer et al., 1998b and Runcie and Durako, 2004). Rapid light curves (RLC) were generated from the calculated ETRs and the irradiances applied during the rapid light curve steps. Each RLC was fitted to a double exponential decay function in order to quantify the characteristic parameters, alpha and ETR $\max _{\text {(Platt et al., }}$ 1980). The initial slope of the RLC $(\alpha)$ is a measure of the light harvesting efficiency of photosynthesis. Alongside the asymptote of the curve, the maximum rate of photosynthesis $\left(E T R_{\max }\right)$, can be used as a measure of the capacity of the photosystems to utilize the absorbed light energy (Marshall et al., 2000). The onset of light saturation $\left(E_{k}\right)$ was calculated as the ratio between ETR $R_{\max }$ and $\alpha$. The polyphasic rise in fluorescence (OJIP) transient depicts the rate of reduction kinetics of various components of PS II. When dark-adapted leaf is illuminated 
with the saturating light intensity of $3500 \mu \mathrm{mol} \mathrm{m} \mathrm{m}^{-2}$, it exhibits a polyphasic OJIP curve. Each letter reflects distinct inflection in the induction curve.

\subsection{Statistical Analyses}

The data was numerically tested for its normality and homogeneity using Statistica Software (Statasoft). Due to the lack of normality and homogeneity, the statistical analyses of the data were based on non-parametric tests. In order to compare species and seasons, the KrustalWallis test was performed using Statistica Software (Statasoft). Spearman correlations were also obtained using the same software. Multidimensional Scalling (MDS) was employed using all attained replicates in order to project the collected samples according to their biotic characteristics. The differences among MDS groups were evaluated using ANOSIM with Primer 6 software (Clarke and Gorley, 2006). The groups were formed according to their degree of similarity as provided by ANOSIM. This test is frequently used in order to compare different communities using the intrinsic provided characteristics of each community, being insensitive to heterogeneous data.

\section{RESULTS}

\subsection{Sediment characteristics}

Although sediment RWC presented similar values among species during the warmest seasons, the differences are striking during cold seasons, with lower values in the sediment colonized by S. versicolor (Fig. 2). Pore water salinity only presented significant inter-specific differences during the summer, with S. versicolor inhabiting sediments with the lowest salinities. Regarding the sediment organic matter, S. maritima muddy sediments always presented higher LOI percentage than S. versicolor sandy sediments. In all the observed patches and probably due to its early stage expansion, S. versicolor was only found in the upper marsh colonizing sandy sediments. Considering sediment $\mathrm{pH}$, no significant differences were observed between the species along the monitored annual period.

\subsection{Sediment and Leaf Carbon and Nitrogen Content and Stable Isotope Signatures}

Carbon $(\mathrm{C}$ ) and nitrogen $(\mathrm{N})$ contents in the sediments colonized by both species (Fig. 3) were found to be similar, presenting only significant differences during summer. It was also found that the sediments colonized by S. maritima presented richer $\mathrm{C}$ and $\mathrm{N}$ contents. Leaf carbon content in both species was found to be similar along the year, with the exception of individuals collected during summer. During this season, S. versicolor showed a significantly higher carbon content. The exact opposite trend could be observed for the $\mathrm{N}$ content, with S. maritima presenting higher $\mathrm{N}$ contents until the end of autumn. With the exception of $\mathrm{S}$. maritima leaves collected during the summer, all the leaves collected from both species, along the annual cycle, 
showed similar stable isotope signatures (Fig. 4). On the contrary, regarding both species sediments stable isotope signatures, there was no clear differentiation neither among species nor seasons. Regarding the correlations between $\mathrm{N}$ sediment and leaf concentrations (Fig. 5), it was possible to observe a high correlation in both species, although this correlation was stronger in S. maritima. If the leaves $\delta^{15} \mathrm{~N}$ are compared with the sediment $\mathrm{N}$ concentration or with the sediment $\delta^{15} \mathrm{~N}$, the strong correlations were only maintained in S. maritima samples.

\subsection{PSII Quantum Efficiencies}

With the exception of the samples collected during spring, S. versicolor had lower operational and maximum PSII efficiencies when compared with S. maritma (Figure 6). The most marked differences were observed during autumn when S. maritima showed an operational PSII efficiency twice that of verified in S. versicolor. This was mostly due to low maximum fluorescence values (F'v value). Once again, $F^{\prime} v$ was different between species, with the exception of the samples assessed during spring. However the dark-adapted variable fluorescence (Fv), measurements showed differences between species for summer and autumn.

\subsection{Rapid Light Curves (RLCs)}

The rETR from both species (Fig. 7) exhibited an optimum maximum at $200 \mu \mathrm{mol}$ photons $\mathrm{m}^{-2} \mathrm{~s}^{-1}$, although with lower transport rates in S. versicolor. At lower light intensities (50 to 100 $\mu \mathrm{mol}$ photons $\mathrm{m}^{-2} \mathrm{~s}^{-1}$ ) both species exhibit similar rETR values. As consequence, $\mathrm{S}$. maritima exhibited higher maximum ETR values especially in during summer and autumn. This also resulted in higher photosynthetic efficiency ( $\alpha$ ) in S. maritima, except during spring where differences between species were not significant. When examining the ratio between these two parameters $\left(E_{k}\right)$, the differences among species are diluted, with only an evident inter-specific separation during the summer, where light intensities are typically higher. During this season, S. maritima had significantly higher $E_{k}$ values.

\subsection{Kautsky Fast Chlorophyll Induction Curves (JIP-test)}

A quick assessment using the Kautsky plots (Fig 8) showed higher values of fluorescence in S. maritma leaves, along all the annual cycle, especially during warm seasons (spring and summer). Analysing the energetic fluxes on a leaf cross-section basis (Fig. 9), there were no significant differences in the energy fluxes between species during winter and spring. On the other hand, during summer and autumn S. maritima showed significantly higher energy absorption per leaf cross section (ABS/CS), and thus also higher trapped (TR/CS) and transported (ET/CS) energy fluxes. During autumn, this increase was mostly due to an increment in the number of reaction centres available for light capture, allowing S. maritima to harvest higher light amounts. 


\subsection{Pigment concentrations}

Some differences were noticed when comparing the chlorophyll concentration between species along the seasonal gradient (Table 2). With the exception of the samples collected during autumn, when S. versicolor had extremely high and significant chlorophyll content, this parameter was found similar in both species during the year. On the other hand, carotenoid content of the $S$. versicolor leaves were higher during autumn. During the warm seasons, carotenoid contents of this specie decreased to values significantly lower than the observed in S. maritima. Considering the ratio between total carotenoids to total chlorophyll, it followed the same trend observed for total carotenoids. However, the $\mathrm{Chl}$ a to $\mathrm{b}$ ratio was found to be significantly lower in S. versicolor during autumn, a pattern that was found to be inverse in the following season, the winter.

\subsection{Multi-dimensional Scaling}

The MDS analysis (Fig. 10) showed a grouping of samples by species and also by sampling season. This separation is explained by differences among highly correlated variables (Spearman correlation coefficient $>0.80$ ). Two major groups were formed by individuals from the same specie collected during the warm seasons (spring and summer). The S. maritima group was characterized by a higher carotenoid content with a comparatively low chlorophyll content, number of active reaction centres, photosynthetic efficiency, ETR $R_{\max }$ and $\delta^{15} \mathrm{~N}$. On the other hand the group formed by $S$. versicolor individuals collected during the warm seasons was mostly associated with the high $\delta^{13} \mathrm{C}$ content and elevated electronic absorption, trapping and dissipated energy fluxes. Two other opposite groups were also formed, joining individuals from both species collected during autumn. The group formed by S. versicolor individuals collected during this season was mostly associated with high chlorophyll content. On the opposite side, the group composed of S. maritima samples collected during the autumn had as common denominator, a high performance index associated with a high electronic transport energy flux and PS II quantum yield. Two other intermediate groups were also observed for the winter samples from both species. The group formed by $S$. maritima samples collected during the winter had high carotenoid contents, while the $S$. versicolor group had high chlorophyll content.

\section{DISCUSSION}

Recently, the expansion of S. versicolor populations has been recorded in the Portuguese marshes (Baumel et al., submitted), where previously there were no records. Due to the high primary production of this species (SanLeon et al., 1999), it becomes important to understand the photosynthetic mechanisms underlying its biomass production using as a reference the well-known mechanisms of the native S. maritima (Duarte et al., 2013). 
Knowing that this new species is in fact a NIS, it becomes crucial to consider its photosynthetic traits as basis for its biomass production and consequent expansion potential. Recently it has been observed a wide spread of this NIS Spartina along several marshes of the Tagus estuary and in several other estuaries from the west coast of Portugal, presenting a wide dispersion in all marshes (Baumel et al., submitted). Air temperature and salinity have already been described as two of the major abiotic drivers in the $C_{4}$ photosynthetic pathway modulation (Duarte et al., 2013). These abiotic drivers directly affect $C_{4}$ photosynthesis, although this is only evident between latitudinal populations, where the climatic differences are more significant (Duarte et al., 2013). In the present study, both species colonize the same marsh and thus are affected by the same climatic conditions. Nevertheless the area occupied by each species has different sediment conditions. Other studies also found abiotic factors intrinsic to the sediments, like salinity, as driving factors for plant biomass production in Spartina alterniflora (Cunha et al., 2005). Considering the two Spartina species studied here, there was no evident relationship between salinity and any of the evaluated photobiological parameters. Nevertheless, periods with higher salinities tend to exacerbate inter-specific differences. This indicates a differential feedback from both species to salinity increase. Although S. maritima is a well-known obligatory halophyte, where salinity plays a key role modulating PSII activity (Mateos-Naranjo et al., 2010; Duarte et al., 2013), this salt-dependence is not evident in S. versicolor, as seen by the relatively stable pattern of all photobiological variables. Sediment $\mathrm{N}$ concentration was already reported as another evident factor affecting S. maritima PSII efficiencies (Duarte et al., 2013). This is in accordance with previous studies that found similar data for other species from the genus Spartina (Madrid et al., 2012). These authors found that an increase in sediment $\mathrm{N}$ content allowed $S$. maritima to incorporate higher $\mathrm{N}$ concentrations, directly correlated with higher PSII maximum quantum yields. If the $\delta^{15} \mathrm{~N}$ stable isotope is considered some more information can be acquired regarding this species $\mathrm{N}$ nutrition. The $\delta^{15} \mathrm{~N}$ of a whole plant is related with its $\mathrm{N}$ sources. In the same way the $\delta^{15} \mathrm{~N}$ of s source like the sediment or the water column is a mean of all potential $\mathrm{N}$ sources weighted by their availabilities (Robinson, 2001). Comparing the stable isotope signature from the leaf $\delta^{15} \mathrm{~N}$ with the sediment $\mathrm{N}$ concentration from both species, strong correlations appear between both variables. The significant relationship between $\delta^{15} \mathrm{~N}$ of shoots and $\mathrm{N}$ content of sediments suggests that, as expected, root uptake is of considerable importance, though there is also $\mathrm{NH}_{4}^{+}$uptake from the water column by leaves (Castro et al., 2007). This was more evident in S. maritima, where the regression line deviates from the 1:1 line. This indicates a higher nitrogen uptake form the water column, due to its exposure to submersion twice per day (Duarte et al., 2014). On the other hand, S. versicolor colonizes sediments with higher elevations in relation to the water column, leading to a prevalence of sediment $\mathrm{N}$ uptake as a preferred $\mathrm{N}$ source. Nevertheless the sediment $\mathrm{N}$ concentration of both species is very similar. This is normally observed in other 
halophytes characteristic from the upper marsh (Castro et al., 2007). While S. maritima colonizes the mudflats, in this marsh, S. versicolor always appears in salt marsh areas with a higher altitude (approximately 1 meter above water level). Besides the lack of relationship between $\delta^{15} \mathrm{~N}$ in the sediments and tissues of $S$. versicolor, all leaf $\delta^{15} \mathrm{~N}$ values were higher than the sediment $\delta^{15} \mathrm{~N}$ values. These data allow a comparison of the fractionation involved in the transfer from sediment to plant tissues, assuming that in fact $\delta^{15} \mathrm{~N}$ of bulk sediment represents the preferential pool from which this specie acquires nitrogen (Castro et al., 2007). Instead, plant roots uptake nitrogen from the more phyto-available pore water source or from the water column (most likely in S. maritima), which presents a different $\delta^{15} \mathrm{~N}$ from the assessed for bulk sediment. These differences in the relationship between tissue $\delta^{15} \mathrm{~N}$ of different species and $\mathrm{N}$ external sources have been reported previously (McClelland and Valiela, 1998). Although these different responses have not been explained mechanistically, these authors relate them to physiological contrasts among the different species of Spartina. Nevertheless both species appear to rely on $\mathrm{NH}_{4}{ }^{+}$uptake during most of the year, although from different sources. Both species leaf $\delta^{15} \mathrm{~N}$ present typical values of $\mathrm{NH}_{4}{ }^{+}$ assimilation into organic $\mathrm{N}$ by plants (Robinson, 2001). The exception is S. maritima summer samples, which present a leaf $\delta^{15} \mathrm{~N}$ typical from the generation of $\mathrm{N}_{2} \mathrm{O}$ and $\mathrm{N}_{2}$ during $\mathrm{NO}_{3}{ }^{-}$ denitrification processes (Robinson, 2001). In fact the role of S. maritima in denitrification was already highlighted in previous works (Sousa et al., 2012).

The photobiology of both species was also evaluated in order to understand the physiological basis of the differences between S. versicolor and the native S. maritima. During most of the evaluated period S. maritima exhibited higher photobiological efficiencies, either in its general response or in its specific activities and energetic fluxes. Rare exceptions were observed in some periods of the year, where both species exhibited some similarities. Again, and as previously mentioned, the abiotic characteristics of the sediments colonized by each species are not enough to explain these differences in their photobiological performance. Although both species were subjected to the same climatic environment, the climate from each original habitat is different. As found in previous studies (Duarte et al., 2013) S. maritima is highly adapted to its native habitat (Mediterranean-Atlantic). Although on a latitudinal basis, the different S. maritima populations exhibit a different photobiological pattern consistent with the latitudinal climatic gradient, at a local scale these differences are not so evident (Duarte et al., 2013). On the other hand, the native climate of S. versicolor is different from the Mediterranean regime, especially in terms of air temperature. Although there is no reference to $S$. versicolor thermal tolerance range, Chmura et al. (2003) points out to a decline in the biomass production of S. patens (the American equivalent of $S$. versicolor) with increasing temperatures. There is an evident relationship between biomass production and air temperature, as previously described (Giurgevich and Dunn, 1979; Drake, 1989; Nobel, 1991), as a consequence of the $C_{4}$-photosynthetic mechanism. This was more evident in $S$. 
versicolor, with a significant negative correlation between average and maximum temperature and the $E_{k}$ values $\left(r^{2}=-0.61\right.$ in both cases, $\left.p<0.05\right)$. Also the minimum air temperatures of the Tagus Estuary negatively influenced this species $\left(r^{2}=-0.71, p<0.05\right)$. Both facts point out to a thermal environment adverse to $S$. versicolor, most probably due to its origin from colder climates (SanLeón et al., 1999; Chmura et al., 2003). Nevertheless, this climatic adversity, S. versicolor always appears in denser and taller turfs that S. maritima. On the other hand, the native S. maritima appears to be highly adapted to the Mediterranean environment showing increased densities of reaction centers and electronic fluxes (absorbed, trapped and electronic) alongside with the thermal regime $\left(r^{2}\right.$ always above 0.69 for all cases with $p$ values bellow 0.05 ). This is in agreement to what was previously recorded for this specie in several estuaries of the Atlantic coast (Duarte et al., 2013). Also the average maximum precipitation seems to have a negative impact on $S$. versicolor operational quantum yield and photosynthetic efficiency $\left(r^{2}=-0.82\right.$ and $-0.65, p<0.05$ respectively), whereas the native $S$. maritima is highly adapted to the rain regime in the Tagus Estuary. This influence is even felt at the nutritional level. Using $\delta^{15} \mathrm{~N}$ isotope signature it is possible to observe an interesting trend in both species. While S. versicolor stable $\delta^{15} \mathrm{~N}$ isotope signature is positively affected by the average rainfall $\left(r^{2}=0.61, p<0.05\right)$, S. maritima exhibits the exact opposite trend $\left(r^{2}=-0.65, p<0.05\right)$. Robinson (2001) found that precipitation is often negatively correlated with leaf $\delta^{15} \mathrm{~N}$ signature, reflecting water availability, and thus local $\mathrm{N}$ cycle processes, especially those involving soil microbes (Handley et al., 1999). This last study also found that foliar $\delta^{15} \mathrm{~N}$ was strongly related to rainfall than the whole soil $\delta^{15} \mathrm{~N}$ (Handley et al., 1999), concomitant with the present data gathered for $S$. versicolor. This evident effect of rainfall on foliar $\delta^{15} \mathrm{~N}$ is largely due to the interaction of growth stimulating effects of adequate moisture (less dry sediments) and increased availability of dissolved $\mathrm{N}$ in the sediments (Handley et al., 1999). This was more evident in S. maritima were rainfall was already described as an enhancing factor of its primary productivity by indirect influence on soil salinity (Mateos-Naranjo et al., 2010; Duarte et al., 2013). On the other hand, S. versicolor showed an increased $\delta^{15} \mathrm{~N}$ in its tissues along the rainfall annual gradient, probably due to a $\delta^{15} \mathrm{~N}$ concentration effect during seasons where biomass production is lower (winter and autumn). In fact, if the seasons are characterized in terms of light environment and rainfall regime, this hypothesis gains support. In Mediterranean ecosystems, winter and autumn are characterized by low light environments and high humidity and precipitation, while spring and summer exhibit the exact inverse pattern. Here two different mechanisms are evidenced by both Spartina species. While S. versicolor concentrates $\mathrm{N}$ in its tissues during low biomass production periods (as observed by the decreased photosynthetic traits during the cold seasons), the high photosynthetic activity of S. maritima during winter is translated into a high biomass production. This is promoted also by a higher $\mathrm{N}$ availability leading to a dilution of the foliar $\delta^{15} \mathrm{~N}$ concentration in the newly formed biomass. With the increasing light intensity 
verified during summer there is a decrease in the foliar $\delta^{15} \mathrm{~N}\left(r^{2}=-0.71, p<0.05\right)$ in S. versicolor due to higher photosynthetic activity and low $\mathrm{N}$ availability in the sediments. In fact, the typical more sandy sediments colonized by S. versicolor are in fact nutritional disadvantage for this specie spreading, being slightly poorer that the mudflats. Gathering all this climatic and physiological information, points to a climatic misfit of $S$. versicolor to the Mediterranean climate while compared to the well-adapted and native S. maritima. Nevertheless its spreading to lower areas of the marsh must be considered as a potential boost for its expansion.

\section{CONCLUSIONS}

A new stressor has recently affected Mediterranean marshes. The presence of NIS can be a threat for the salt marshes biodiversity, depending on its ecophysiological fitness in this new environment. This proved to be the major constrains shaping S. versicolor ecophysiological fitness, its primary productivity and consequently its spread along the Mediterranean marshes. In contrast to the native S. maritima, the NIS S. versicolor proved to have a lower photosynthetic fitness under the Mediterranean climate, which seems to be slowing down its spread but not arresting it. Also, this NIS N-nutrition appears to be on of the factors impairing it spreading at higher rates. Thus, as the on-going climatic changes can be favouring drivers for a faster expansion of this species, taking part of less productive Mediterranean species in a climate change scenario, the need arises to monitor this NIS and consider its advance as a potential threat to the ecosystem biodiversity.

\section{ACKNOWLEDGMENTS}

The authors would like to thank to the "Fundação para a Ciência e Tecnologia (FCT)" for funding the research in the Marine and Environmental Sciences Centre (MARE) throughout the project UID/MAR/04292/2013 and this specific work throughout the ECOSAM project (PTDC/AACCLI/104085/2008). B. Duarte investigation was supported by FCT throughout a PhD grant (SFRH/BD/75951/2011) and throughout the COST action TD1209 (COST-STSM-TD1209-16451).

\section{REFERENCES}

Ainouche, M., Baumel, A., Salmon, A. and Yannic, G., 2003. Hybridization, polyploidy and speciation in Spartina (Poaceae). New Phytologist 161, 165-172.

Álvarez, R., Castillo, J.M., Mateos-Naranjo, E., Gandullo, J., Rubio-Casal, A.E., Moreno, F.J. and Figueroa, M.E., 2010. Ecotypic variations in phosphoenolpyruvate carboxylase activity of the cordgrass Spartina densiflora throughout its latitudinal distribution range. Plant Biology 12, 154160. 
Bailey, K., Gray, J., Walker, R. and Leegood R., 2007. Coordinate regulation of phosphoenolpyruvate carboxylase and phosphoenolpyruvate carboxykinase by light and CO2 during C4 photosynthesis. Plant Physiology 144, 479-486.

Baumel, A., Ainouche, M. L., Bayer, R.J., Ainouche, A. K. and Misset, M.T., 2002. Molecular Phylogeny of Hybridizing Species from the genus Spartina Schreb. (Poaceae). Molecular Phylogenetics and Evolution 22. 303-314.

Baumel, A., Rousseau-Gueutin, M., Sapienza-Bianchi, C., Gareil, A., Duong, N., Coriton, O., Amirouche, R., Duarte, B., Caçador, I., Castillos, J. and Ainouche, M. Native or introduced? The status of Spartina versicolor Fabre. Submitted to Biological Invasions.

Beer, S., Ilan, M., Eshel, A., Weil, A. and Brickner I., 1998a. The use of pulse amplitude modulated (PAM) fluorometry for in situ measurements of photosynthesis in two Red Sea Faviid corals. Marine Biology 131, 607-612.

Beer, S., Vilenkin, B., Weil, A., Veste, M., Susel, L., and Eshel, A., 1998b. Measuring photosynthesis in seagrasses by pulse amplitude modulated (PAM) fluorometry. Marine Ecology Progress. Series $174,293-300$.

Castro, P., Valiela, I. and Freitas, H., 2007. Eutrophication in Portuguese estuaries evidenced by $\delta 15 \mathrm{~N}$ of macrophytes. Marine Ecology Progress Series 351, 43-51.

Chmura, G.L., Anisfeld, S.C., Cahoon, D.R. and Lynch, J.C., 2003. Global carbon sequestration in tidal, saline wetland soils. Global Biogeochemical Cycles 17, 1111.

Clarke, K.R., Gorley, R.N., 2006. PRIMER v6: User Manual/Tutorial. PRIMER-E, Plymouth.

Cosson, E. and Durieu de Maisonneuve, 1867. Introduction á la flore d'Algérie. Phanérogamie. Groupe des Glumacées (seu descriptio glumacearum in Algeria nascentium). Exploration Scientifique de l'Algérie, publiée par ordre du Gouvernement. Sciences Naturelles. Botanique. Imprimerie Impériale. Paris.

Cunha, S., Asmus, M. and Costa, C., 2005. Production dynamics of Spartina alterniflora salt marshes in the estuary of Patos Lagoon (RS, Brazil): a simulation model approach. Brazilian Journal of Aquatic Science and Technology 9, 75-85.

Daehler, C. C. and Strong, D. R., 1996. Status, prediction and prevention of introduced cordgrass Spartina spp. invasions in Pacific estuaries, U.S.A. Biological Conservation 78, 51-58. 
Daehler, C., Anttila, C., Ayres, D. and Strong, D., 1999. Evolution of a new ecotype of Spartina alterniflora (Poaceae) in San Francisco Bay, California, USA. American Journal of Botany 86, 543546.

Douglas, E., Jacobs, J., Sumner, D. and Ray, R., 2009. A comparison of models for estimating potential evapotranspiration for Florida land cover types. Journal of Hydrology 373, 366-376.Drake, B. G. 1989. Photosynthesis of Salt Marsh Species. Aquatic Botany 34, 167-1180.

Duarte, B., Couto, T., Freitas, J., Valentim, J., Silva, H., Marques, J. C. and Caçador, I., 2013 Abiotic modulation of Spartina maritima photosynthetic ecotypic variations in different latitudinal populations. Estuarine, Coastal and Shelf Science 130, 127-137.

Duarte, B., Raposo, P., Caçador, I., 2009. Spartina maritima (cordgrass) rhizosediment extracellular enzymatic activity and its role on organic matter decomposition and metal speciation processes. Marine Ecology 30, 65-73.

Duarte, B., Reboreda, R., Caçador, I. 2008. Seasonal variation of Extracellular Enzymatic Activity (EEA) and its influence on metal speciation in a polluted salt marsh. Chemosphere, 73, 1056-1063.

Duarte, B., Santos, D., Marques, J.C. and Caçador, I., 2014. Biophysical probing of Spartina maritima Photo-system II changes during increased submersion periods: possible adaptation to sea level rise. Plant Physiology ad Biochemistry 77, 122-132.

Fabre, M.E., 1849. Description d'une nouvelle espèce de Spartina, abondante sur une portion du littoral méditerranéen. Annales des Sciencies Naturelles. Botanique. Paris, 3, 122-125.

Fernald, M. L., 1929. Some relationships of the floras of the northern hemisphere. Proccedings of the International Congress on Plant Science 2, 1487-1507.

Genty, B., Briantais J.-M., Baker, N., 1989. The relationship between the quantum yield of photosynthetic electron transport and quenching of chlorophyll fluorescence. Biochimica et Biophysica Acta 990, 87-92.

Giurgevich, J.R. and Dunn, E.L., 1979. Seasonal Patterns of CO2 and Water Vapor Exchange of the Tall and Short Height Forms of Spartina alterniflora Loisel in a Georgia Salt Marsh. Oecologia 43, 139-156.

Handley, L.L., Austin, A.T., Robisn, D., Scrimgeour, C.M., Raven, J.A., Heaton, T.H.E., Schmidt, S. and Stewart, G.R., 1999. The ${ }^{15} \mathrm{~N}$ natural abundance $\left(\delta^{15} \mathrm{~N}\right)$ of ecosystem samples reflects measures of water availability. Australian Journal of Plant Physiology 26, 185-199. 
Hatch M., 1992. C4 photosynthesis: an unlikely process full of surprise. Plant Cell Physiology 33, 333-342.

Heide O., 2005. Ecotypic variation among European arctic and alpine populations of Oxyda digyna. Arctic, Antarctic and Alpine Research, 37, 233-238.

Heywood, V. H., 1989. Patterns, extends, and modes of invasions by terrestrial plants. In Biological invasions: A global perspective, edited by J. A. Drake, H. A. Mooney, F. DiCastri, R. H. Groves, F. J. Kruger, M. Rejmanek, and M. Williams, 31-60. New York: John Wiley.

Hultén, E., 1958. The amphi-atlantic plants and their phytogeographical connections. Almquist \& Wiksell. Stockholm.

Kupper, H., Seibert, S. and Aravind, P., 2007. A fast, sensitive and inexpensive alternative to analytical pigment HPLC: quantification of chlorophylls and carotenoids in crude extracts by fitting with Gauss-Peak-Spectra. Analytical Chemistry 79, 7611-7627.

Lara M., Casati P. and Andreo C., 2001. In vivo phosphorylation of phosphoenolpyruvate carboxylase in Egeria densa, a submersed aquatic species. Plant Cell Physiology 42, 441-445.

Lessmann J., Mendelssohn I., Hester M. and McKee K., 1997. Population variation in growth response to flooding of three marsh grasses. Ecological Engineering 8, 31-47.

Madrid, E., Armitage, A. and Quigg, A., 2012. The Response of Photosystem II to Soil Salinity and Nutrients in Wetland Plant Species of the Northwestern Gulf of Mexico. Journal of Coastal Research 28, $1197-1207$.

Marchant, C. and Goodman, P., 1969. Spartina maritima (Curtis) Fernald. Journal of Ecology 57, 287-291.

Marshall, H., Geider, R. and Flynn, K., 2000. A mechanistic model of photoinhibition. New Phytologist 145, 347-359.

Mateos-Naranjo, E., Redondo-Gómez, S., Andrades-Moreno, L. and Davy, A., 2010. Growth and photosynthetic responses of the cordgrass Spartina maritima to $\mathrm{CO} 2$ enrichment and salinity. Chemosphere 81, 725-731.

McClelland, J.W. and Valiela, I., 1998. Linking nitrogen in estuarine producers to land-derived sources. Limnology and Oceanography 43, 577-585.

Mobberley, D. G., 1956. Taxonomy and distribution of the genus Spartina. lowa State College Journal of Sciences 30, 471-574. 
Nobel, P. S. 1991. Physicochemical and Environmental Plant Physiology. Academic Press, California. $635 \mathrm{pp}$.

Otero X., Sanchez, J. and Macías F., 2000. Nutrient status in tall and short forms of Spartina maritima in the salt marshes of Ortigueira (NW Iberian Peninsula) as related to physicochemical properties of the soils. Wetlands 20, 461-469.

Planty-Tabacchi, A.-M., Tabacchi, E. and Bonillo, M.J.S., 2001. Invasions of river corridors by exotic plant species: patterns and causes. In: Brundu, G., Brock, J., Camarda, I., Child, L. and Wade, M. (Eds): Plant invasions: species ecology and ecosystem management. Backuys Publishers, Leiden, pp. 221-233.

Planty-Tabacchi, A.-M., Tabacchi, E., Naiman, R.J., DeFerrari, C. and Decamps, H., 1996. Invasibility of species-rich communities in riparian zones. Conservation Biology 10, 598-607.

Platt, T., Gallegos, C. and Harrison W., 1980. Photoinhibition of photosynthesis in natural assemblages of marine phytoplankton. Journal of Marine Research 38, 687-701.

Proffitt, C., Chiasson, R., Owens, A., Edwards, K. and Travis, S., 2005. Spartina alterniflora genotype influences facilitation and suppression of high marsh species colonizing an early successional salt marsh. Journal of Ecology 93, 404-416.

Robinson, D., 2001. $\delta^{15} \mathrm{~N}$ as an integrator of the nitrogen cycle. TRENDS in Ecology and Evolution 16, 153-162.

Runcie, J. and Durako, M., 2004. Among-shoot variability and leaf-specific absorbance characteristics affect diel estimates of in situ electron transport of Posidonia australis. Aquatic Botany 80, 209-220.

SanLeon, D.G., Izco, J. and Sanchez, J.M., 1999. Spartina patens: a weed in Galician saltmarshes (NW Iberian Peninsula). Hydrobiologia 15, 213-222.

Seliskar, D., Gallagher, J., Burdick, D. and Mutz, L., 2002. The regulation of ecosystem functions by ecotypic variation in the dominant plant: a Spartina alterniflora salt-marsh case study. Journal of Ecology 90, 1-11.

Sousa, A.I., Lillebø, A.I., Risgaard-Petersen, N., Pardal, M.A. and Caçador, I., 2012. Denitrification: an ecosystem service provided by salt marshes. Marine Ecology Progress Series 448, 79-92.

Stephenson D., Oliver, L., Burgos, N. and Gbur E., 2006. Identification and characterization of pitted morningglory (Ipomoea lacunose) ecotypes. Weed Science 54, 78-86. 
Thiébaut, C., 2007. Pièces encochées moustériennes et enlèvements mécaniques: peut-on les distinguer? In: Un siècle de construction du discours scientifi que en Préhistorie, Congrès du Centenaire de la Société Préhistorique Française, 26ème session du Congrès Préhistorique de France, Avignon, 21-25 septembre 2004, vol. 3, p. 201-216.

Turc, L., 1961. Évaluation des Besoins en Eau D’Irrigation, Évapotranspiration Potentielle. Annales Agronomiques 12, 13-49.

Tutin, T.G., 1980. Spartina Schreber. In: Tutin, T.G., Heywood, V.H., Burges, N.A., Moore, D.M., Valentine, D.H., Walters, S.M., Webb, D.A. (eds.) Flora Europaea, Vol. 5. Cambridge, UK: Cambridge University Press, 259-260.

Van der Maarel, E. and Van der Maarel-Versluys, M., 1996. Distribution and conservation status of littoral vascular plant species along the European coasts. Journal of Coastal Conservation 2, 73-92.

Vidal J., Pierre J. and Echevarría C., 1996. The regulatory phosphorylation of C4 phosphoenolpyruvate carboxylase, a cardinal event in C4 photosynthesis. In: Dennis T.S., Hohn B., King P.G., Schell G., Verma D.P.S. (Eds), Plant Gene Research. Signal Transduction in Plant Growth and Development. Springer-Verlag, New York: 141-160.

\section{Figure Captions}

Figure 1. Tagus Estuary detail with Hortas salt marsh location.

Figure 2. Sediment physico-chemical characteristics in pure stands colonized by S. versicolor and $S$. maritima for the study period (average \pm standard deviation, $n=5 .{ }^{*}$ indicates significant differences between species at $p<0.05$ ).

Figure 3. Foliar and sediment carbon and nitrogen contents in S. versicolor and S. maritima along the study period (average \pm standard deviation, $n=5$. * indicates significant differences between species at $p<0.05)$.

Figure 4. Foliar and sediment seasonal $\delta^{15} \mathrm{~N}$ and $\delta^{13} \mathrm{C}$ isotopic signatures in $\mathrm{S}$. versicolor and $\mathrm{S}$. maritima for the study period (average \pm standard deviation, $n=5 .{ }^{*}$ indicates significant differences between species at $p<0.05$ ).

Figure 5. Linear correlations between average seasonal foliar and sediment $\delta^{15} \mathrm{~N}$ and $\mathrm{N}$ contents in S. versicolor and S. maritima (average \pm standard deviation, $n=5 .{ }^{*}$ indicates significant differences between species at $p<0.05)$.

Figure 6. Variable fluorescence and PSII quantum yields in light and dark adapted leaves of $S$. versicolor and S. maritima for the study period (average \pm standard deviation, $\mathrm{n}=5$. * indicates significant differences between species at $p<0.05)$. 
Figure 7. Rapid light curves derived rETR in dark-adapted leaves of S. versicolor and S. maritima for the study period (average \pm standard deviation, $n=5$. * indicates significant differences between species at $p<0.05)$.

Figure 8. RLCS derived parameters in S. versicolor and S. maritima leaves for the study period (average \pm standard deviation, $\mathrm{n}=5$. * indicates significant differences between species at $p<0.05$ ). Figure 9. Chlorophyll transient kinetics (OJIP curves) in dark-adapted leaves of S. versicolor and $S$. maritima for the study period (average \pm standard deviation, $n=5$.).

Figure 10. Energetic fluxes spider-plots in dark-adapted leaves of S. versicolor and S. maritima for the study period (average \pm standard deviation, $n=5 . *$ indicates significant differences between species at $p<0.05)$.

Figure 11. MDS projection of the S. maritima and S. versicolor samples collected during the study period with the strongly correlated biotic parameters $\left(r^{2}>0.80\right)$. 


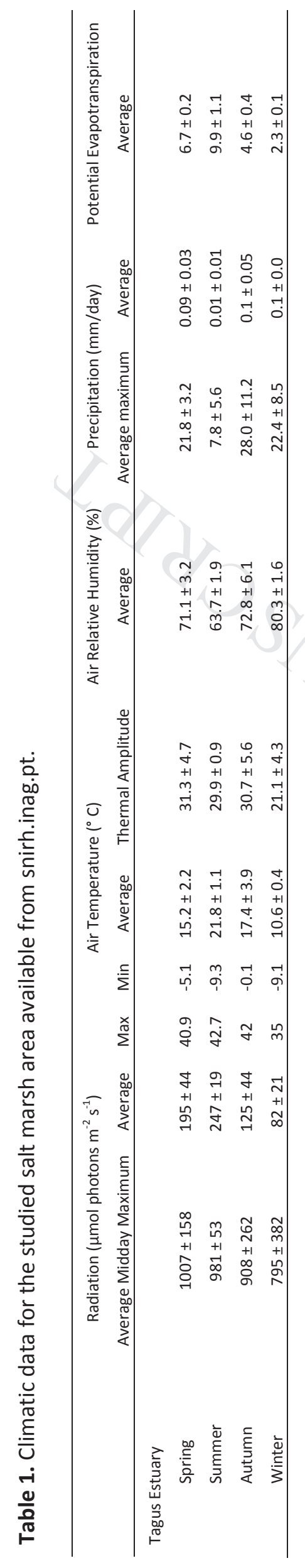


Table 2. Pigment content $\left(\mu \mathrm{g} \mathrm{g}^{-1}\right)$ and ratios in the leaves of S. maritima and S. versicolor collected along the year (average \pm standard deviation, $n=5 . *$ indicates significant differences between species at $p<0.05$ ).

\begin{tabular}{llllll}
\hline \multicolumn{2}{c}{ Total Chlorophylls } & Total Carotenoids & Chl a/b & Total Chl/ Carot \\
\hline Autumn & & & & & \\
& S. versicolor & $1283.37 \pm 129.21^{*}$ & $566.40 \pm 80.94^{*}$ & $2.32 \pm 0.47^{*}$ & $0.44 \pm 0.03^{*}$ \\
& S. maritima & $247.45 \pm 43.44^{*}$ & $128.54 \pm 18.51^{*}$ & $3.58 \pm 0.03^{*}$ & $0.53 \pm 0.02^{*}$ \\
\hline Winter & & & & \\
& S. versicolor & $512.62 \pm 40.21$ & $391.93 \pm 24.78$ & $2.36 \pm 0.36^{*}$ & $0.78 \pm 0.10^{*}$ \\
& S. maritima & $525.27 \pm 39.12$ & $535.34 \pm 22.07$ & $1.64 \pm 0.03^{*}$ & $1.03 \pm 0.07^{*}$ \\
\hline \multirow{2}{*}{ Spring } & & & & \\
& S. versicolor & $414.00 \pm 83.13$ & $266.18 \pm 38.87^{*}$ & $3.14 \pm 0.14$ & $0.67 \pm 0.06$ \\
& S. maritima & $774.41 .82 \pm 130.67$ & $477.23 \pm 34.77^{*}$ & $2.79 \pm 0.36$ & $0.64 \pm 0.08$ \\
\hline Summer & & & & \\
& S. versicolor & $336.82 \pm 37.12$ & $186.61 \pm 13.43^{*}$ & $2.23 \pm 0.17$ & $0.56 \pm 0.02^{*}$ \\
& S. maritima & $552.96 \pm 92.58$ & $399.24 \pm 62.80^{*}$ & $2.06 \pm 0.20$ & $0.73 \pm 0.02^{*}$
\end{tabular}



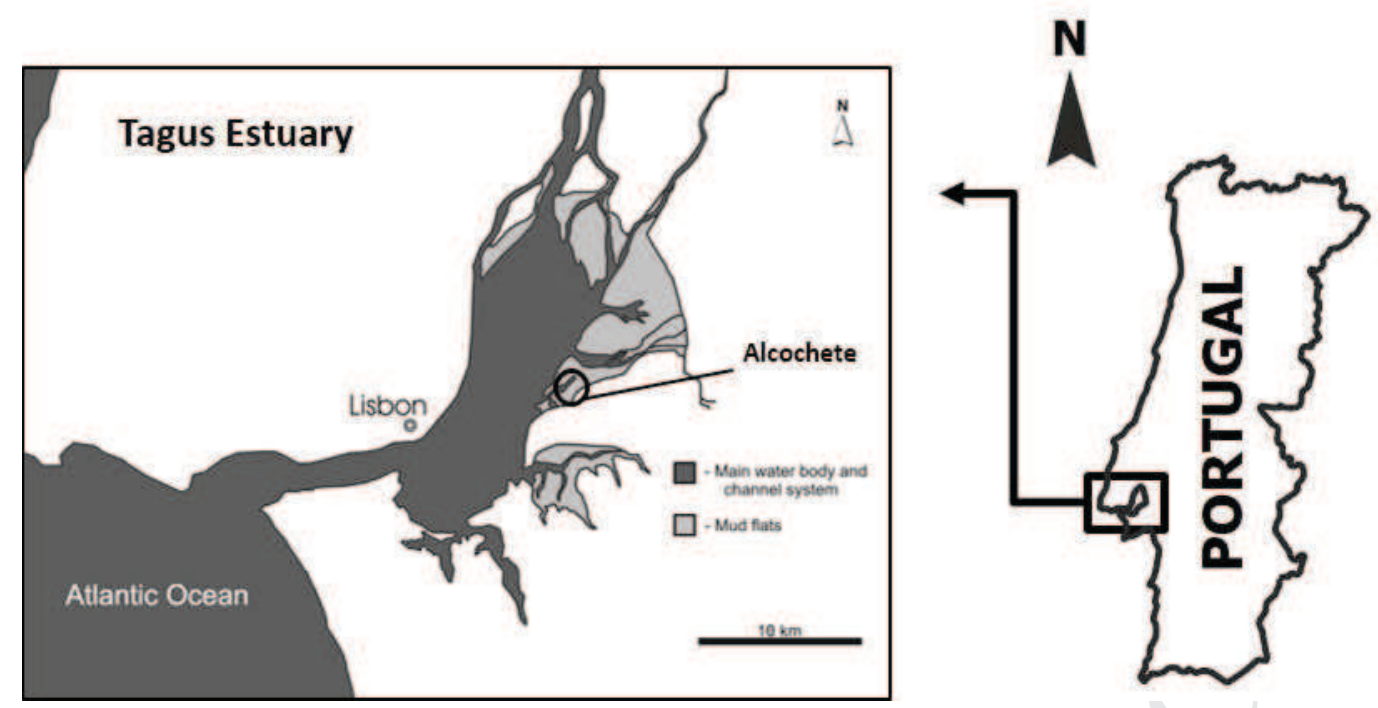

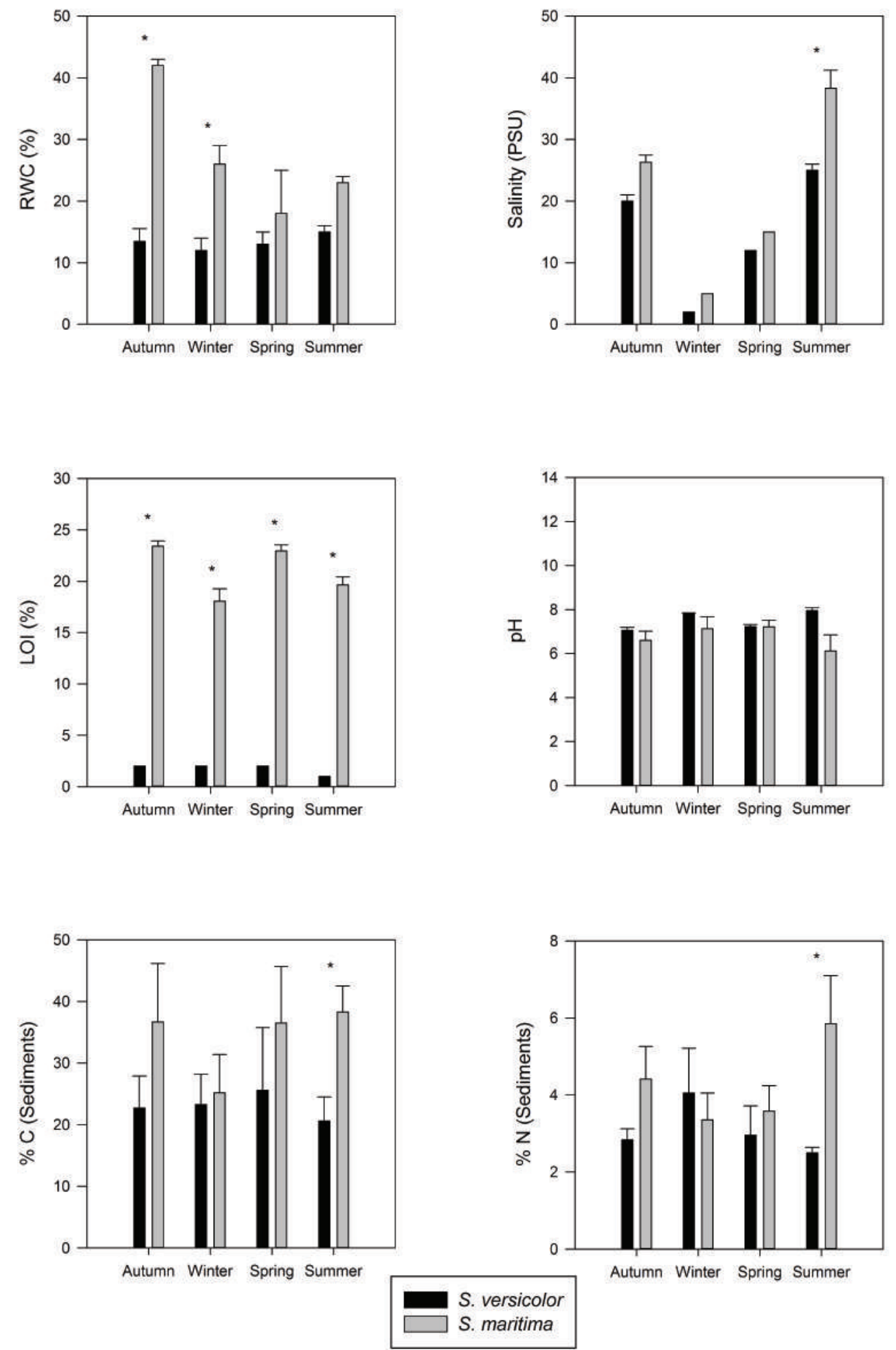

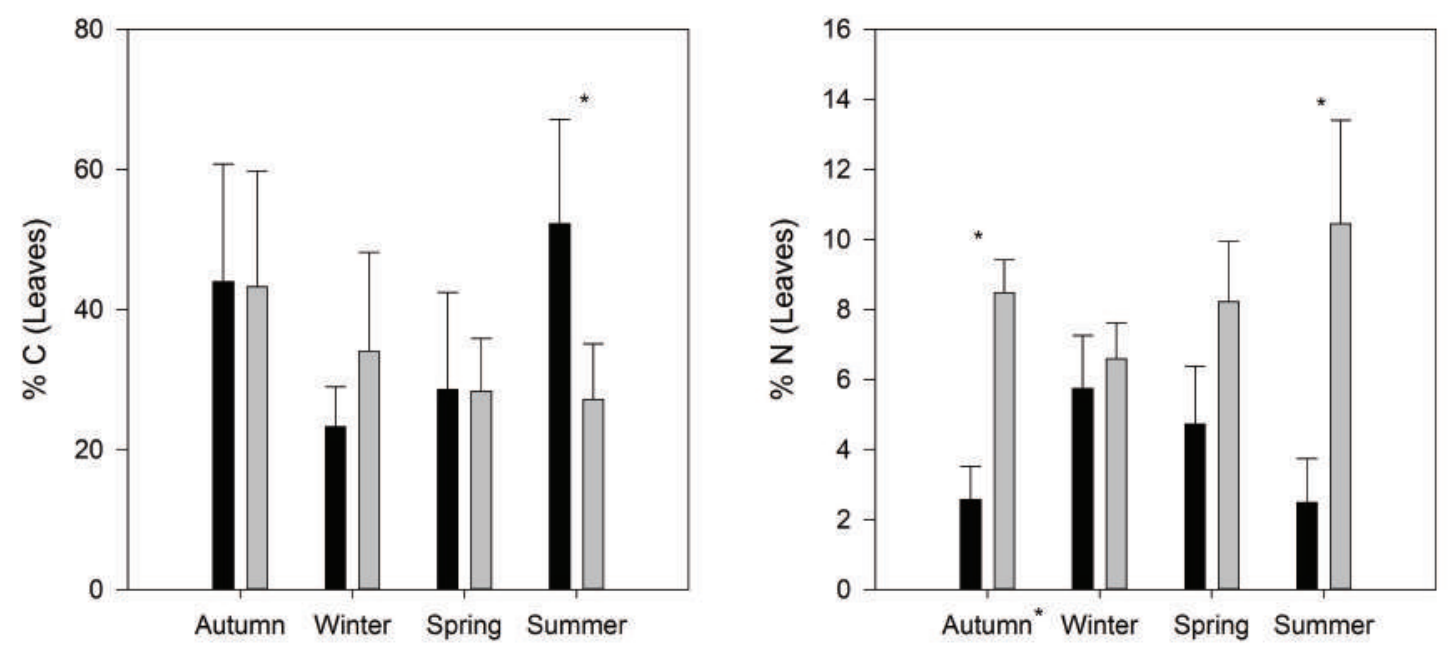

S. versicolor
S. maritima 

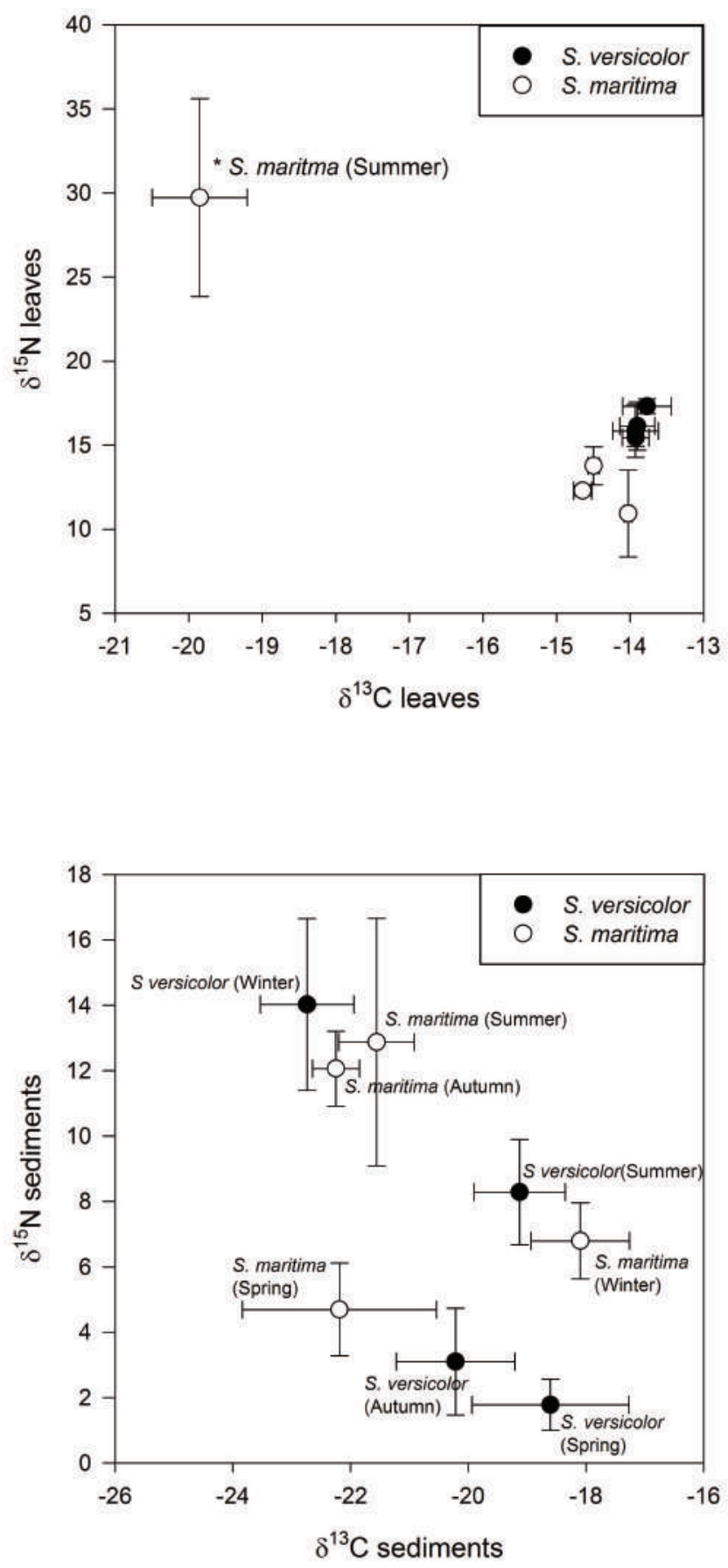

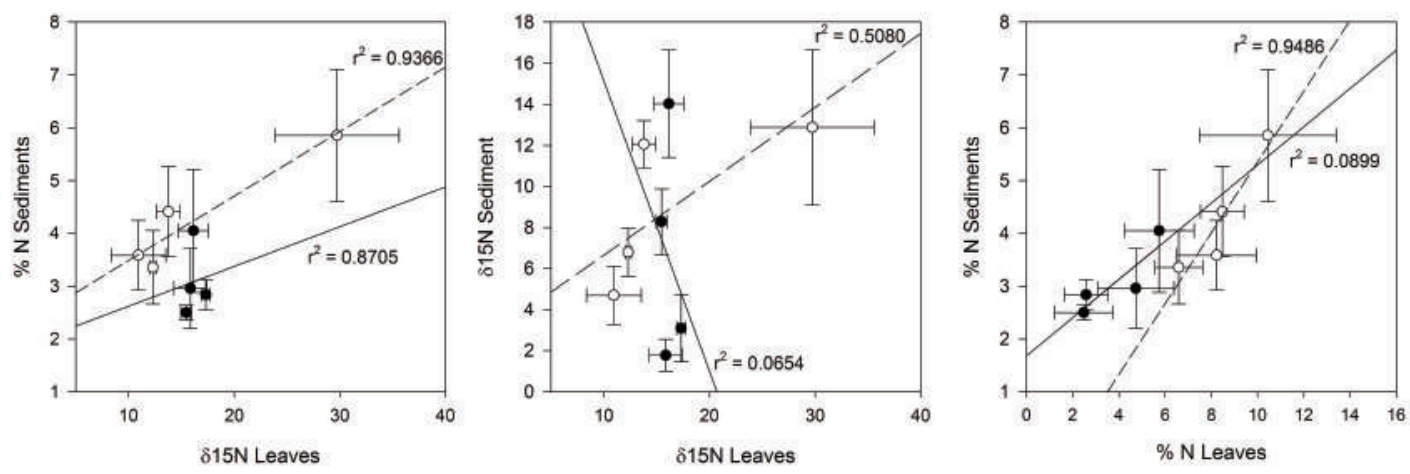

- S. versicolor

- S. versicolor linear regression S. manitma linear regression 

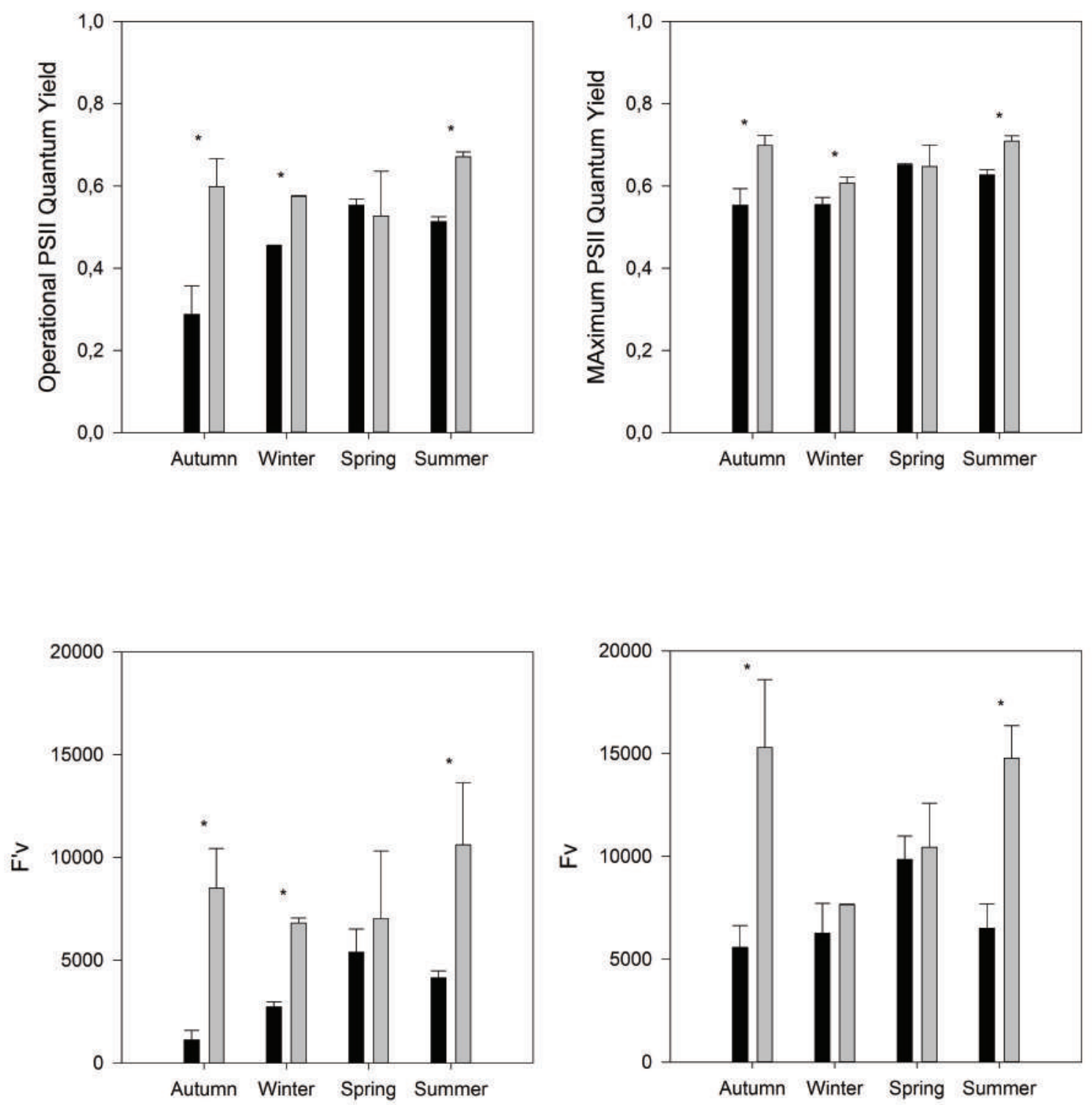
Autumn

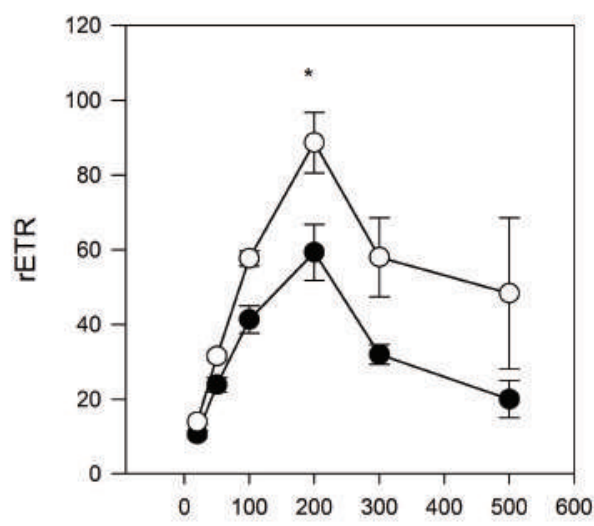

PAR ( $\mu$ mol photons $\mathrm{m}^{-2} \mathrm{~s}^{-1}$ )

Spring

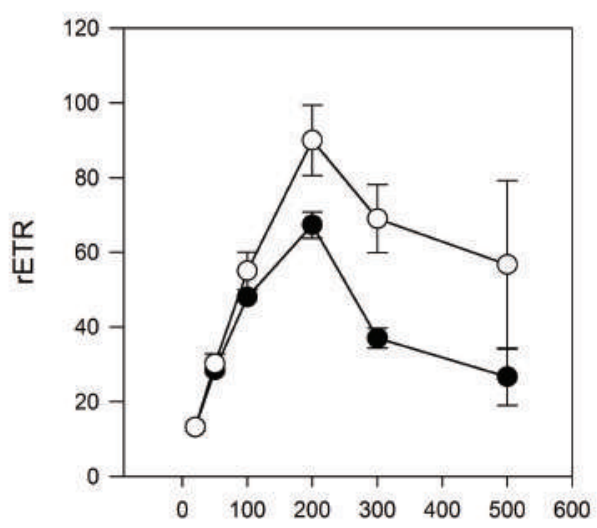

PAR ( $\mu$ mol photons $\mathrm{m}^{-2} \mathrm{~s}^{-1}$ )

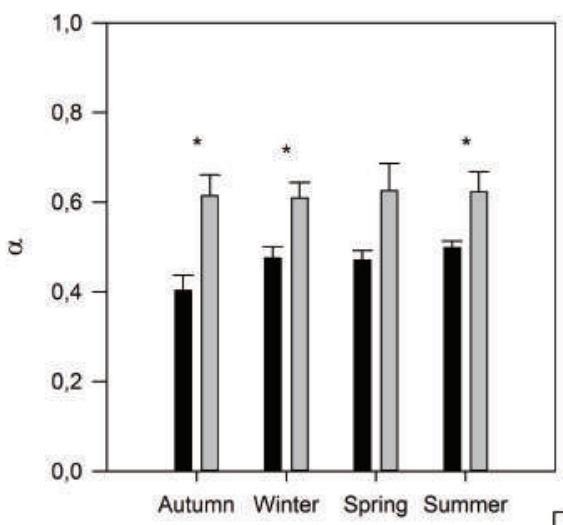

Winter

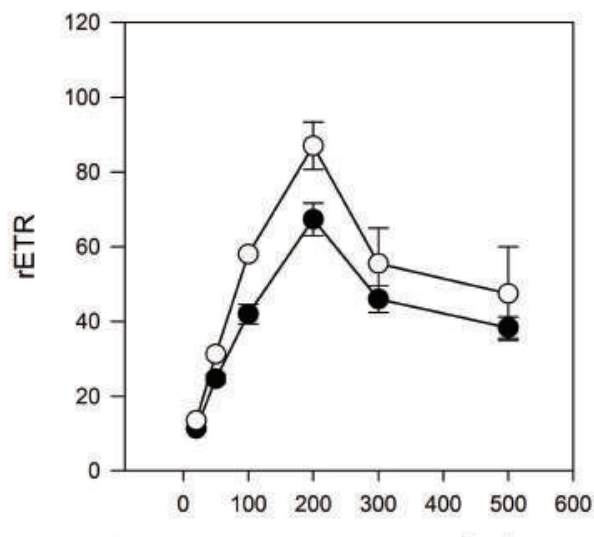

PAR ( $\mu \mathrm{mol}$ photons $\mathrm{m}^{-2} \mathrm{~s}^{-1}$ )

Summer
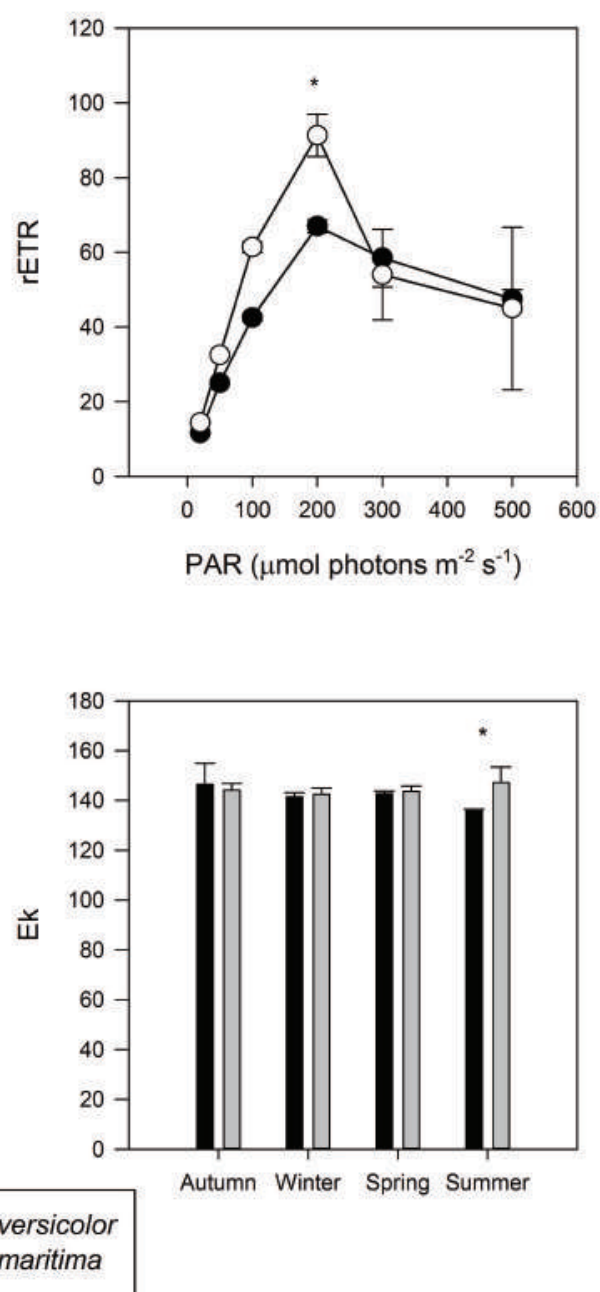
Autumn

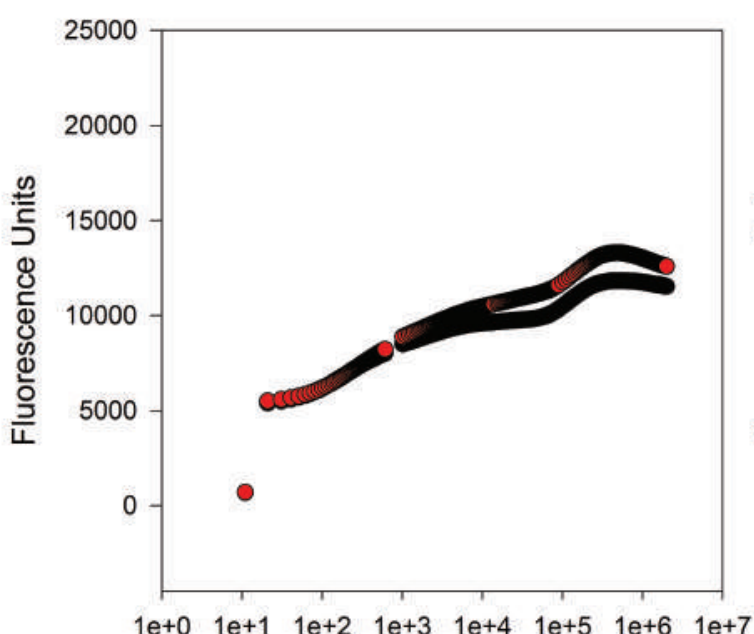

$\log _{10}$ time $(\mu \mathrm{s})$

Spring

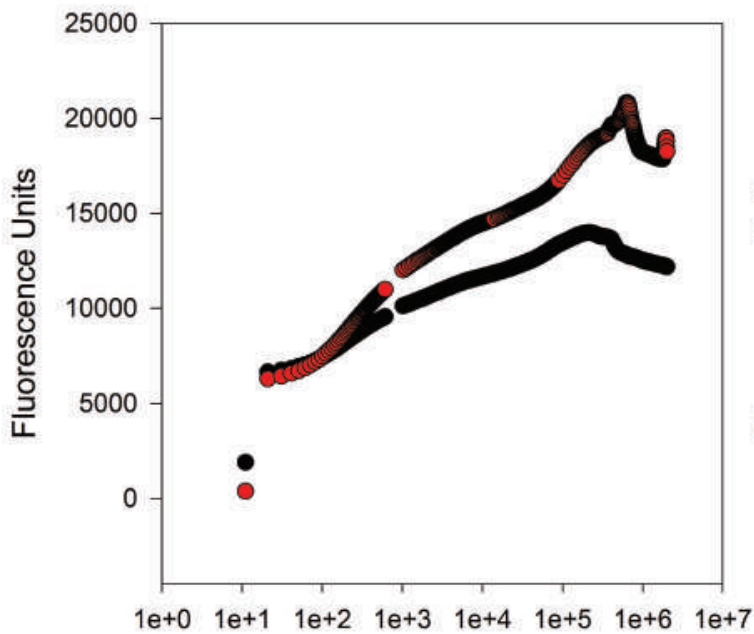

$\log _{10}$ time $(\mu \mathrm{s})$
Winter

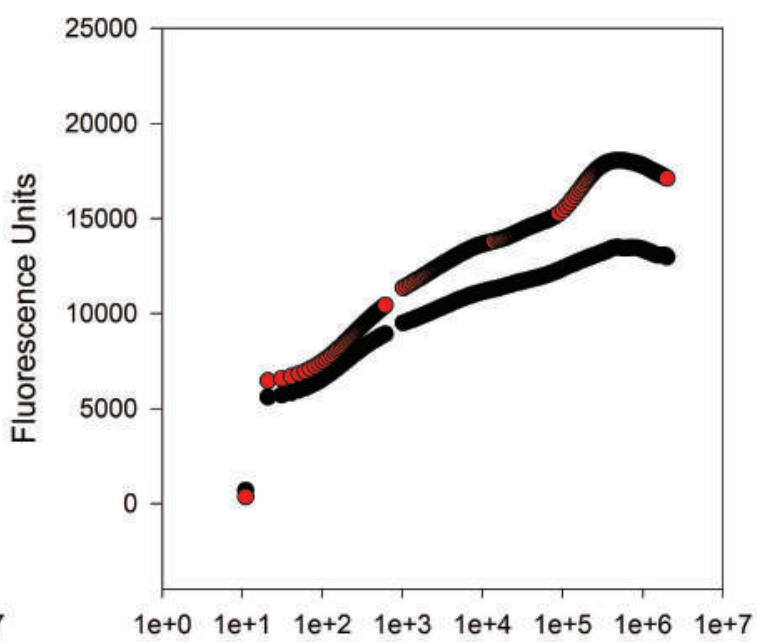

$\log _{10}$ time $(\mu \mathrm{s})$

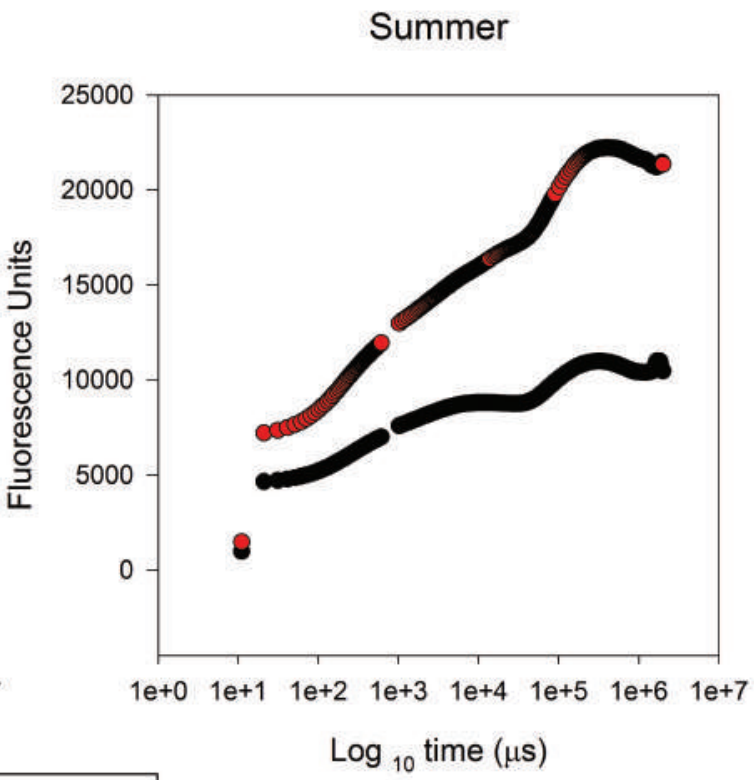

S. versicolor S. maritima 

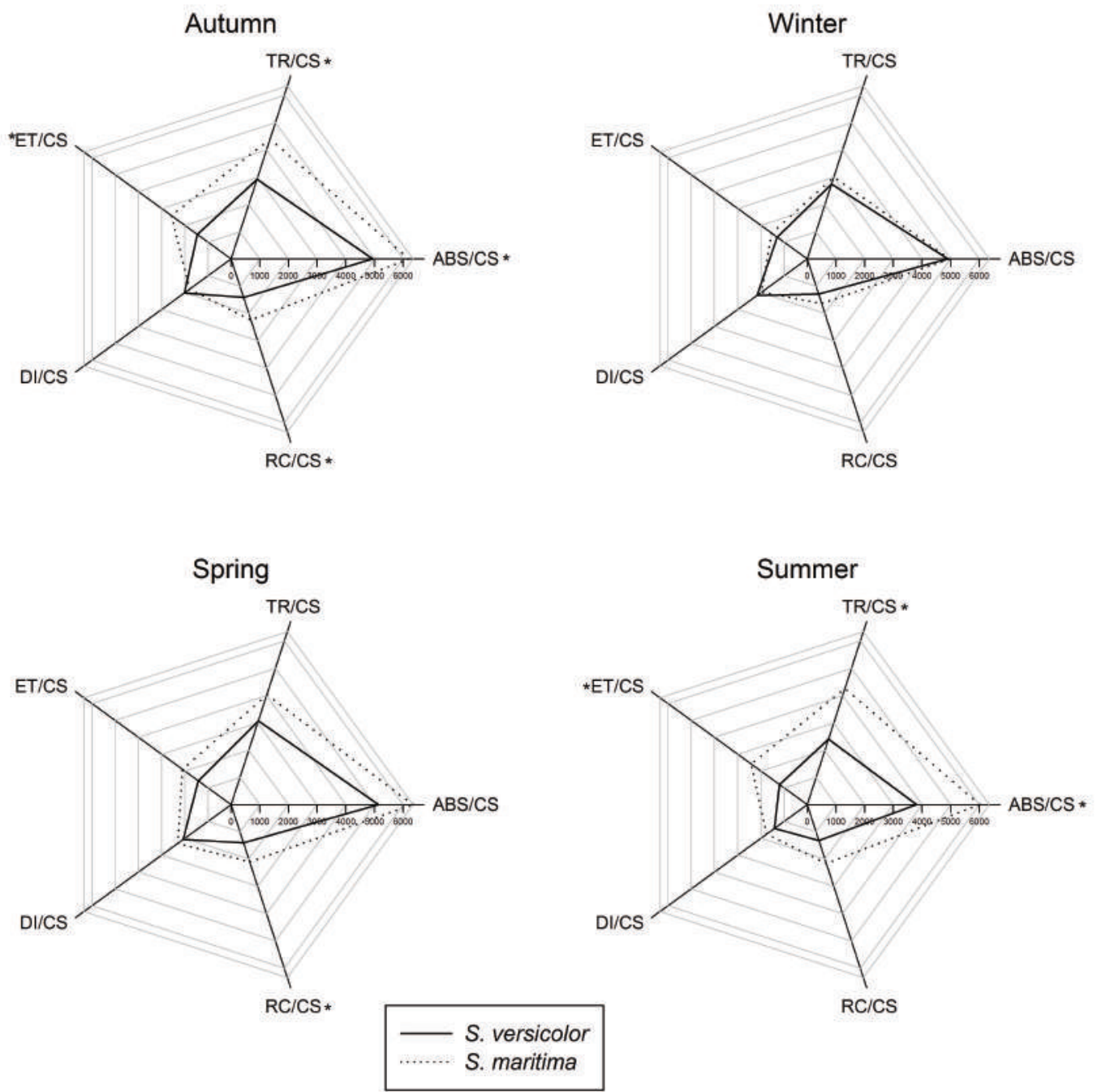


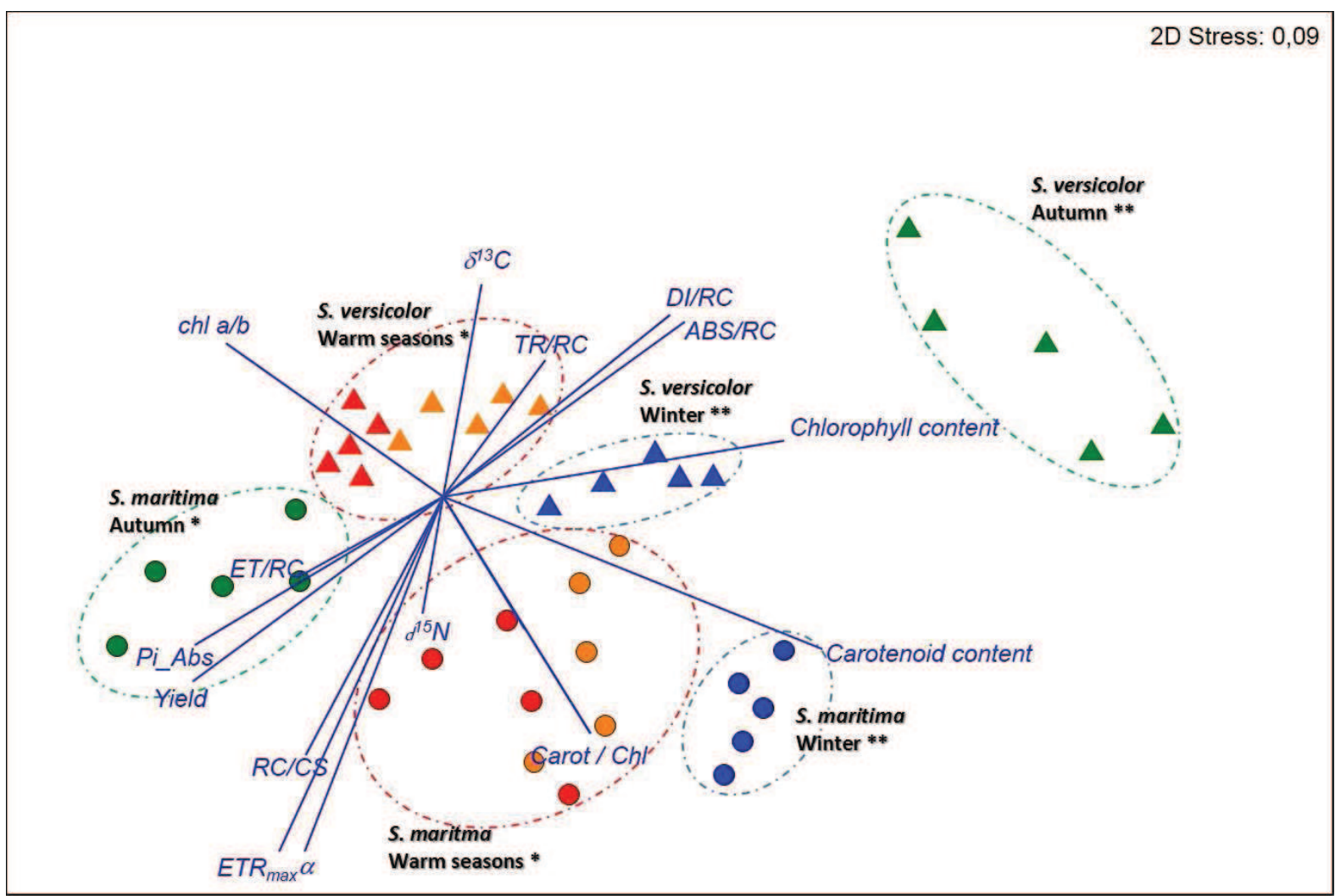

